\title{
An Appraisal of Drug-Drug Interactions with Green Tea (Camellia sinensis)
}

Authors

Ahmed A. Albassam ${ }^{1}$, John S. Markowitz ${ }^{2,3}$

Affiliations

1 Department of Clinical Pharmacy, College of Pharmacy, Prince Sattam Bin Abdulaziz University, Al-Kharj, Kingdom of Saudi Arabia

2 Department of Pharmacotherapy and Translational Research, University of Florida College of Pharmacy, Gainesville, Florida, USA

3 Center for Pharmacogenomics, University of Florida, Gainesville, Florida, USA

Key words

green tea, Camellia sinensis, Theaceae, epigallocatechin gallate, cytochrome P450, uridine 5'-diphospho-glucuronosyltransferase, transporter, herb-drug interaction

received October 28, 2016

revised December 28, 2016

accepted January 10, 2017

Bibliography

DOI http://dx.doi.org/10.1055/s-0043-100934

Published online January 24, 2017 | Planta Med 2017; 83: 496-508 @ Georg Thieme Verlag KG Stuttgart · New York | ISSN 0032-0943

Correspondence

Ahmed A. Albassam, Ph.D.

Assistant Professor

Department of Clinical Pharmacy, College of Pharmacy, Prince Sattam Bin Abdulaziz University

P. O. Box 173, Al-Kharj 11942, Kingdom of Saudi Arabia

Phone: + 966115886052 , Fax: + 966115886001

aa.albassam@psau.edu.sa

\section{ABSTRACT}

This review summarizes published in vitro, animal, and clinical studies investigating the effects of green tea (Camellia sinensis) extract and associated catechins on drug-metabolizing enzymes and drug transporters. In vitro studies suggest that green tea extract and its main catechin, (-)-epigallocatechin3-gallate, to varying degrees, inhibit the activity of CYP1A1, CYP1A2, CYP2B6, CYP2C8, CYP2C9, CYP2D6, and CYP3A4. UGT1A1 and UGT1A4 isoforms were also inhibited by (-)-epigallocatechin-3-gallate. Animal studies suggest green tea extract and/or (-)-epigallocatechin-3-gallate significantly increase the bioavailability of diltazem, verapamil, tamoxifen simvastatin, 5-fluorouracil, and nicardipine. Conversely, green tea extract and/or (-)-epigallocatechin-3-gallate reduce the bioavailability of quetiapine, sunitinib, clozapine, and nadolol. Of the few clinical studies available for review, it appears neither green tea extract nor (-)-epigallocatechin-3-gallate inhibit any major cytochrome P450 enzyme. Regarding drug transporters, in vitro studies indicate P-glycoprotein, organic anion transporting polypeptide $1 \mathrm{~A} 1$, organic anion transporting polypeptide $1 \mathrm{~B} 1$, organic anion transporting polypeptide $1 \mathrm{~B} 3$, organic anion transporting polypeptide $2 \mathrm{~B} 1$, organic cation transporter 1 , organic cation transporter 2 , multidrug and toxin extrusion 1 , and multidrug and toxin extrusion 2-K are potentially inhibited by green tea extract. A clinical study indicates the organic anion transporting polypeptide $1 \mathrm{~A} 1$ transporter is inhibited by (-)-epigallocatechin-3-gallate while P-glycoprotein is unaffected. In conclusion, the ingestion of green tea extract or its associated catechins is not expected to result in clinically significant influences on major cytochrome P450 or uridine 5'-diphosphoglucuronosyltransferase enzyme substrates or drugs serving as substrates of P-glycoprotein. However, some caution is advised in the consumption of significant amounts of green tea beverages or green tea extract in patients prescribed known substrates of organic anion transporting polypeptide, particularly those with a narrow therapeutic index.

\section{Introduction}

Tea is one of the most popular and widely consumed beverages in the world. Tea is prepared from the leaves of the plant Camellia sinensis L., which belong to the family Theaceae [1]. White tea, oolong tea, black tea, and green tea are all harvested from this plant, but are processed differently and attain different levels of oxidation [2]. Green tea is a non-fermented (non-oxidized) tea and as such contains a greater catechin content than either black tea or oolong tea. To produce green tea, freshly harvested leaves are stabilized by dry heating or steaming to inactivate polyphenol oxidase enzymes and then are dried rapidly, thereby preserving much of the tea's polyphenol content [1]. Green tea originated in China and subsequently spread to the surrounding Asian countries, both as a beverage and in use for its medicinal properties. 


\author{
ABBREVIATIONS \\ Caco-2 colon carcinoma-derived cell lines \\ CHO Chinese hamster ovary cell line \\ CYP cytochrome P450 \\ EC (-)-epicatechin \\ ECG (-)-epicatechin-3-gallate \\ EGC (-)-epigallocatechin \\ EGCG (-)-epigallocatechin-3-gallate \\ GTCs green tea catechins \\ GTE green tea extract \\ GTPs green tea polyphenols \\ HEK human embryonic kidney \\ HIMs human intestinal microsomes \\ HLMs human liver microsomes \\ LS-180 human gastrointestinal epithelial cell line \\ OATP organic anion transporting polypeptide \\ P-gp P-glycoprotein \\ R-123 rhodamine-123 \\ UGT uridine 5'-diphospho-glucuronosyltransferase
}

The majority of purported therapeutic benefits of green tea are attributed to catechins, a class of flavonoids that exert potent antioxidant activity ( $\bullet$ Fig. $\mathbf{1}$ ). The major catechin present in green tea is EGCG, which accounts for up to $50 \%$ of total polyphenol content and possesses the highest antioxidant potential of any tea catechin assessed [2,3]. Other catechins found in green tea in lesser abundance include ECG, EGC, and EC [4]. The high catechin content is suggested to underpin the significant antioxidant properties of green tea and its proposed protective roles in a host of pathological conditions caused by reactive oxygen species [5]. Green tea/EGCG has been reported to produce a number of positive health benefits, including cancer chemoprevention, improved cardiovascular health, enhanced weight loss, improved glycemic control, and other favorable effects [5-10].

Because of the widespread and regular use of green tea as a beverage and/or dietary supplement, the concurrent use of the plant extract with one or more conventional medications is essentially unavoidable. Importantly, a number of botanical extracts are recognized as posing a drug interaction liability when combined with conventional therapeutics [11]. Pharmacokinetic drug interactions in particular remain a significant clinical concern. The majority of botanical-drug interactions involve the drug metabolizing enzymes (DMES) CYP and UGT, as well as selected drug transporters. The pharmacokinetic-based dietary supplement-drug interactions may occur through the alteration of drug absorption, distribution, metabolism, and/or excretion. The modulation of intestinal enzymes as well as the uptake and efflux transporters by herbal or phytochemical supplements may affect the rate and extent of drug absorption. However, the modulation of hepatic/ renal uptake and efflux transporters and/or the inhibition/induction of DMEs can affect the drug's metabolism and excretion significantly in some instances. Most of the reported supplementdrug interactions are caused by the modulation of DMEs and/or

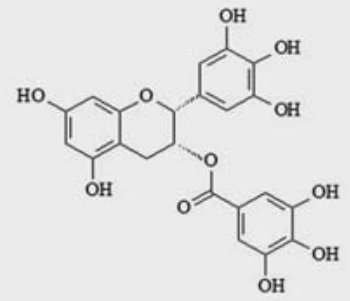

Epigallocatechin-3-gallate (EGCG)



Epigallocatechin (EGC)

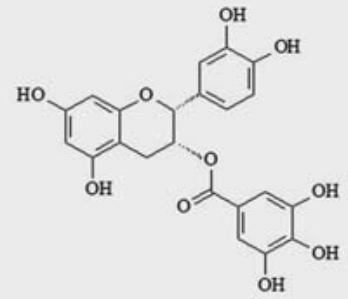

Epicatechin-3-gallate (ECG)

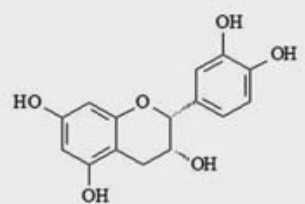

Epicatechin (EC)
- Fig. 1 Selected major catechins typically present in green tea extracts.

transporters in the intestine and liver, which could lead to therapeutic failure or toxicity.

A number of in vitro, animal, and clinical studies have been conducted to evaluate the potential of green tea or one or more of its constituents to modulate the activity of DMEs and/or drug transporters. Accordingly, the primary aim of the present paper is to review and summarize studies with regard to the potential of green tea or its constituents to interact with DMEs and/or drug transporters.

\section{Methods}

Computerized systematic literature searches were conducted in MEDLINE (PubMed) and Google Scholar databases through September 2016 to retrieve all pertinent studies, reviews, and case reports. Cross-referencing of published bibliographies yielded some additional reports. Drug interaction assessments were divided into three main categories: i) in vitro studies, ii) animal studies, and iii) clinical studies, which included case reports. The search terms that were utilized were green tea or Camellia sinensis or epigallocatechin gallate (EGCG) in combination with the terms cytochrome P450, CYP, or uridine 5'-diphospho glucuronosyltransferase, UGT, and transporter as well as the terms inhibition and induction. Only papers published in the English language were evaluated. No other limitations were applied.

\section{Results}

An array of in vitro, animal, and clinical drug interaction studies involving green tea or one or more of its components employing various study paradigms, drug substrates, and assessment tools 
- Table 1 In vitro studies evaluating the effect of GTEs on enzyme activity.

\begin{tabular}{|c|c|c|c|c|}
\hline $\begin{array}{l}\text { Green tea preparation } \\
\text { and exposure }\end{array}$ & Enzyme substrate & System & Result & Reference \\
\hline \multirow[t]{2}{*}{ EGCG and ECG } & \multirow[t]{2}{*}{$\begin{array}{l}\text { CYP1A1 (Ethoxycoumarin) } \\
\text { CYP1A2 (Ethoxyresorufin) } \\
\text { CYP2A6 (Coumarin) } \\
\text { CYP2C9 (Diclofenac) } \\
\text { CYP2E1 (Nitrophenol) } \\
\text { CYP3A4 (Midazolam) }\end{array}$} & \multirow[t]{2}{*}{$\begin{array}{l}\text { cDNA-expressed } \\
\text { isoenzyme } \\
\text { (S. typhimurinm TA } 1538 \text { cells) }\end{array}$} & $\begin{array}{l}\text { Catechins } \\
\downarrow \text { CYP1A1 } \\
\downarrow \text { CYP1A2 } \\
\downarrow \text { CYP3A4 } \\
\leftrightarrow \text { CYP2C9 } \\
\leftrightarrow \text { CYP2E1 } \\
\leftrightarrow \text { CYP2A6 }\end{array}$ & \multirow[t]{2}{*}[12]{} \\
\hline & & & $\begin{array}{l}\text { EGCG } \\
\downarrow \text { CYP1A1 } 1 \text { Ki } 17 \mu \mathrm{M}) \\
\downarrow \text { CYP1A2 (Ki } 10 \mu \mathrm{M}) \\
\downarrow \text { CYP3A4 (Ki } 41 \mu \mathrm{M}) \\
\downarrow \text { CYP2C9 (Ki } 18 \mu \mathrm{M}) \\
\downarrow \text { CYP2E1 }(\text { Ki } 58 \mu \mathrm{M}) \\
\downarrow \text { CYP2A6 (Ki } 13 \mu \mathrm{M})\end{array}$ & \\
\hline GTE & $\begin{array}{l}\text { CYP2C9 (Tolbutamide) } \\
\text { CYP2D6 (Bufuralol) } \\
\text { CYP3A4 (Testosterone) }\end{array}$ & HLM & $\begin{array}{l}\downarrow \text { CYP2C9 (IC } 5057 \mu \mathrm{g} / \mathrm{mg} \text { protein) } \\
\downarrow \text { CYP2D6 (IC } 5050 \mu \mathrm{g} / \mathrm{mg} \text { protein) } \\
\downarrow \text { CYP3A4 (IC } 5063 \mu \mathrm{g} / \mathrm{mg} \text { protein) }\end{array}$ & [13] \\
\hline \multirow[t]{7}{*}{$\begin{array}{l}\text { GTC } \\
\text { (EGCG, ECG, EGC, } \\
\text { and EC) }\end{array}$} & \multirow[t]{2}{*}{ CYP3A4 (Irinotecan) } & HLM & $\begin{array}{l}\text { EGC } 10 \mu \mathrm{M} \\
\downarrow \mathrm{CYP3A4} 35 \% \\
\text { EGCG, ECG, EC } 100 \mu \mathrm{M} \\
\downarrow \mathrm{CYP} 3 \mathrm{~A} 447 \%\end{array}$ & \multirow[t]{7}{*}[14]{} \\
\hline & & Hepatocytes & $\begin{array}{l}\text { GTC } \\
\leftrightarrow \text { CYP3A4 }\end{array}$ & \\
\hline & \multirow[t]{5}{*}{ UGT1A1 (Irinotecan) } & HLM & $\begin{array}{l}\text { ECG, EGCG } 100 \mu \mathrm{M} \\
\downarrow \text { UGT1A1 } 80 \%\end{array}$ & \\
\hline & & Hepatocytes & $\begin{array}{l}\text { EGCG } 2 \mu \mathrm{M} \\
\uparrow \mathrm{UGT} 1 \mathrm{~A} 160-160 \% \\
\text { ECG } 2 \mu \mathrm{M} \\
\uparrow \mathrm{UGT} 1 \mathrm{~A} 140-130 \%\end{array}$ & \\
\hline & & Hep G2 cell & $\begin{array}{l}\text { EGC } 2 \mu \mathrm{M} \\
\text { i UGT1A1 50-80\% }\end{array}$ & \\
\hline & & \multirow[t]{2}{*}{$\begin{array}{l}\text { UGT1A1 mRNA expressed in } \\
\text { hepatocytes }\end{array}$} & $\begin{array}{l}\text { GTC } 2 \mu \mathrm{M} \\
\leftrightarrow \mathrm{UGT} 1 \mathrm{~A} 1\end{array}$ & \\
\hline & & & $\begin{array}{l}\text { GTC } 2 \mu \mathrm{M} \\
\leftrightarrow \mathrm{UGT} 1 \mathrm{~A} 1\end{array}$ & \\
\hline \multirow[t]{4}{*}{$\begin{array}{l}\text { GTE } \\
\text { EGCG }\end{array}$} & \multirow[t]{2}{*}{$\begin{array}{l}\text { CYP2B6 (Bupropion) } \\
\text { CYP2C8 (Amodiaquine) } \\
\text { CYP2C19 (S-mephenytoin) } \\
\text { CYP2D6 (Dextromethorphan) } \\
\text { CYP3A4 (Midazolam) }\end{array}$} & \multirow[t]{2}{*}{ HLM } & $\begin{array}{l}\text { GTE } \\
\downarrow \text { CYP2B6 IC } 506 \mu \mathrm{g} / \mathrm{mL} \\
\downarrow \text { CYP2C8 IC } 505 \mu / \mathrm{mL} \\
\downarrow \text { CYP3A4 IC } 5014 \mu \mathrm{g} / \mathrm{mL} \\
\leftrightarrow \text { CYP2C19 IC } 5049 \mu \mathrm{g} / \mathrm{mL} \\
\leftrightarrow \text { CYP2D6 IC } 5025 \mu \mathrm{g} / \mathrm{mL}\end{array}$ & \multirow[t]{3}{*}[15]{} \\
\hline & & & $\begin{array}{l}\text { EGCG } \\
\downarrow \text { CYP2B6 IC } C_{50} 8 \mu \mathrm{M} \\
\downarrow \text { CYP2C8 IC } 5011 \mu \mathrm{M} \\
\downarrow \text { CYP3A4 IC } 5023 \mu \mathrm{M} \\
\leftrightarrow \text { CYP2C19IC IC } 501 \mu \mathrm{M} \\
\leftrightarrow \text { CYP2D6 IC } 5069 \mu \mathrm{M}\end{array}$ & \\
\hline & \multirow[t]{2}{*}{ CYP3A4 (Midazolam) } & \multirow[t]{2}{*}{ HIM } & $\begin{array}{l}\text { GTE } \\
\downarrow \text { CYP3A4 IC } 5018 \mu \mathrm{g} / \mathrm{mL}\end{array}$ & \\
\hline & & & $\begin{array}{l}\text { EGCG } \\
\downarrow \text { CYP3A4 IC } 5031 \mu \mathrm{M}\end{array}$ & continued \\
\hline
\end{tabular}




\begin{tabular}{|c|c|c|c|c|}
\hline $\begin{array}{l}\text { Green tea preparation } \\
\text { and exposure }\end{array}$ & Enzyme substrate & System & Result & Reference \\
\hline \multirow[t]{7}{*}{$\begin{array}{l}\text { GTE } \\
\text { EGCG }\end{array}$} & \multirow[t]{4}{*}{$\begin{array}{l}\text { mRNA expression } \\
\text { CYP1A1 CYP1A2 } \\
\text { CYP3A4 }\end{array}$} & \multirow[t]{2}{*}{ LS-180 cell line } & $\begin{array}{l}\text { GTE } \\
\uparrow \text { CYP1A2 7-fold } \\
\leftrightarrow \text { CYP1A1 } \\
\leftrightarrow \text { CYP3A4 }\end{array}$ & \multirow[t]{7}{*}{ [16] } \\
\hline & & & $\begin{array}{l}\text { EGCG } \\
\leftrightarrow \text { CYP1A2 } \\
\leftrightarrow \text { CYP1A1 } \\
\leftrightarrow \text { CYP3A4 }\end{array}$ & \\
\hline & & \multirow[t]{2}{*}{ Caco-2 } & $\begin{array}{l}\text { GTE } \\
\uparrow \text { CYP1A1 25-fold } \\
\uparrow \text { CYP1A2 6-fold } \\
\leftrightarrow \text { CYP3A4 }\end{array}$ & \\
\hline & & & $\begin{array}{l}\text { EGCG } \\
\uparrow \text { CYP1A15-fold } \\
\uparrow \text { CYP1A2 3-fold } \\
\leftrightarrow \text { CYP3A4 }\end{array}$ & \\
\hline & \multirow[t]{3}{*}{$\begin{array}{l}\text { CYP1A2 } \\
\text { CYP3A4 }\end{array}$} & \multirow{3}{*}{$\begin{array}{l}\text { Expressed in insect cell } \\
\text { membranes Measuring the } \\
\text { luminescent signal of CYP1A2 } \\
\text { demthylation and CYP3A4 } \\
\text { debnezylation by }\end{array}$} & $\begin{array}{l}\text { GTE } 0.1 \mathrm{mg} / \mathrm{mL} \\
\downarrow \text { CYP1A2 } 45 \%\end{array}$ & \\
\hline & & & $\begin{array}{l}\text { GTE } 1 \mathrm{mg} / \mathrm{mL} \\
\downarrow \text { CYP3A4 45\% }\end{array}$ & \\
\hline & & & $\begin{array}{l}\text { EGCG } 402 \mu \mathrm{M} \\
\downarrow \text { CYP1A2 45\% } \\
\downarrow \text { CYP3A4 25\% }\end{array}$ & \\
\hline $\begin{array}{l}\text { GTC } \\
\text { (C, EC, ECG, EGC, CG, } \\
\text { GC, GCG, EGCG) }\end{array}$ & $\begin{array}{l}\text { CYP1A2 } \\
\text { CYP2C9 } \\
\text { CYP2D6 } \\
\text { CYP34A }\end{array}$ & HLM & $\begin{array}{l}\text { CG } \\
\downarrow \text { CYP2C9 IC } 507.6 \mu \mathrm{M} \\
\text { EGCG } \\
\downarrow \text { CYP1A2 IC } 508.9 \mu \mathrm{M}\end{array}$ & {$[17]$} \\
\hline EGCG & $\begin{array}{l}\text { UGT1A4 } \\
\text { UGT1A6 } \\
\text { UGT1A9 }\end{array}$ & HLM & $\downarrow$ UGT1A4 IC $5074 \mu \mathrm{M}$ & {$[18]$} \\
\hline EGCG & UGT1A1 & HLM & $\downarrow$ UGT1A1 IC $5017 \mu \mathrm{M}$ & {$[19]$} \\
\hline
\end{tabular}

were retrieved and reviewed. Findings from these reports are summarized and presented in $>$ Tables 1-4 and are specifically discussed in the ensuing sections.

\section{In vitro interaction assessments}

There are a number of recognized limitations of in vitro screening methodologies used to assess potential botanical supplementdrug interactions. These limitations include the arbitrary assignment of drug concentration at the enzymatic and/or drug transporter site, difficulties accounting for or even estimating pre-systemic metabolism, and the contribution of both known and unknown metabolites. Additionally, single botanical constituents are often used in testing, which are not reflective of typical multi-constituent extracts that are ingested [41]. In spite of these limitations, in vitro studies remain the mainstay of the initial evaluation of promising lead compounds in conventional medicine, and the assessment of botanical compounds in the pre- and post-marketing periods. The widespread use of in vitro methods is largely due to the high throughput nature of these investigations and the substantially reduced costs relative to in vivo studies. Furthermore, "positive" results, particularly if replicated and at physio- logically relevant concentrations, can serve as the basis for the performance of more rigorous clinical studies. Studies of green tea employing in vitro methodologies are highlighted in $>$ Tables 1 and 2.

\section{Cytochrome P450 enzymes}

\section{Metabolic inhibition}

Screening for metabolic inhibition of one or more hepatic enzymes (e.g., CYP 450) has become one of the more routine (and in some instances required) assessments of a conventional drug or dietary supplement proposed for clinical use. The effects of green tea catechins on CYP enzymes were studied by Muto and colleagues utilizing a genetically modified cell line and they were found to inhibit several of the enzymes assessed [12]. The catechins evaluated as potential inhibitors in the study were obtained from Sigma-Aldrich with the exception of EGCG, which was obtained from Wako Pure Chemical Industries. The inhibitory effect of green tea catechins on human CYP1A1, CYP1A2, CYP2A6, CYP2C9, CYP2E1, and CYP3A4 were examined in genetically engineered Salmonella typhimurinm TA 1538 cells. Whilst all catechins inhibited all of the tested CYP activity to some degree, EGCG was 
- Table 2 In vitro studies evaluating effect of green tea on transporter activity.

\begin{tabular}{|c|c|c|c|c|}
\hline $\begin{array}{l}\text { Green tea preparation } \\
\text { and exposure }\end{array}$ & Transporter & System & Result & Reference \\
\hline GTE & \multirow[t]{2}{*}{$\begin{array}{l}\text { Estrone-3-sulfate } \\
\text { OATP-B }\end{array}$} & \multirow[t]{2}{*}{$\begin{array}{l}\text { Human embryonic kidney } \\
293 \text { cells (HEK293) }\end{array}$} & $\begin{array}{l}\downarrow \text { OATP-B } \\
82 \%\end{array}$ & \multirow[t]{2}{*}{ [20] } \\
\hline EGCG & & & $75 \%$ & \\
\hline \multirow{5}{*}{$\begin{array}{l}\text { EGCG } \\
\text { ECG }\end{array}$} & Estrone-3-sulfate & & & \multirow[t]{5}{*}{ [21] } \\
\hline & OATP1A2 & HEK293 & ECG & \\
\hline & \multirow[t]{3}{*}{$\begin{array}{l}\text { OATP1B1 } \\
\text { OATP1B3 } \\
\text { OATP2B1 }\end{array}$} & \multirow[t]{3}{*}{$\mathrm{CHO}$ cells } & $\begin{array}{l}\downarrow \text { OATP1A2 IC } 5010 \mu \mathrm{M} \\
\downarrow \text { OATP1B1 IC } 5059 \mu \mathrm{M} \\
\downarrow \text { OATP2B1 IC } 5036 \mu \mathrm{M} \\
\uparrow \text { OATP1B3 }\end{array}$ & \\
\hline & & & $\begin{array}{l}\text { EGCG } \\
\downarrow \text { OATP1A2 IC } 5055 \mu \mathrm{M} \\
\downarrow \text { OATP1B1 IC } 508 \mu \mathrm{M} \\
\downarrow \text { OATP2B1 IC } 50101 \mu \mathrm{M}\end{array}$ & \\
\hline & & & $\begin{array}{l}\text { EGCG } 30-300 \mu \mathrm{M} \\
\uparrow \text { OATP1B3 } 5 \text {-fold }\end{array}$ & \\
\hline GTE & Nadolol (OATP1A2) & HEK293 & $\downarrow$ OATP1A2 & {$[22]$} \\
\hline \multirow[t]{3}{*}{$\begin{array}{l}\text { GTE } \\
\text { EGCG }\end{array}$} & \multirow[t]{3}{*}{$\begin{array}{l}\text { P-glycoprotein (P-gp) } \\
\text { MRP2 (Methotrexate) } \\
\text { (Glutathione methylfuorescein) }\end{array}$} & \multirow[t]{3}{*}{ LS- 180 cell line } & $\begin{array}{l}\text { GTE } 0.01 \mathrm{mg} / \mathrm{mL} \\
\leftrightarrow \mathrm{P}-\mathrm{gP} \\
\leftrightarrow \mathrm{MRP} 2\end{array}$ & \multirow[t]{3}{*}{ [23] } \\
\hline & & & $\begin{array}{l}\text { GTE } 1 \mathrm{mg} / \mathrm{mL} \\
\downarrow \text { MRP2 ( } \uparrow 2 \text {-fold of methotrexate } \\
\text { permeability) } \\
\leftrightarrow \text { P-gP }\end{array}$ & \\
\hline & & & $\begin{array}{l}\text { EGCG } \\
\leftrightarrow \mathrm{P}-\mathrm{gP} \\
\leftrightarrow \mathrm{MRP2}\end{array}$ & \\
\hline GTP & \multirow[t]{2}{*}{ P-gp } & \multirow[t]{2}{*}{$\mathrm{CHO}$ cell line } & $\begin{array}{l}\text { GTP } 10 \mu \mathrm{g} / \mathrm{mL} \\
\downarrow \text { P-gp } 50 \% \text { photolabeling } \\
\text { ( } \uparrow \text { accumulation of R- } 123 \text { by } 2.2 \text {-fold } \\
\text { with } 15 \mu \mathrm{g} / \mathrm{mL} \text { ) }\end{array}$ & \multirow[t]{2}{*}[24]{} \\
\hline EGCG & & & $\begin{array}{l}\text { EGCG } 100 \mu \mathrm{M} \\
\text { ( } \uparrow \text { accumulation of R-123 by } 4 \text {-fold) }\end{array}$ & \\
\hline \multirow[t]{6}{*}{$\begin{array}{l}\text { GTE } \\
\text { EGCG }\end{array}$} & \multirow{2}{*}{$\begin{array}{l}\text { OATP1B1 } \\
\text { OATP1B3 } \\
\text { [Bromosulphophthalein (BSP), } \\
\text { atorvastatin] }\end{array}$} & \multirow[t]{2}{*}{ HEK } & $\begin{array}{l}\text { GTE with BSP } \\
\downarrow \text { OATP1B1 IC } 502.6 \%(\mathrm{v} / \mathrm{v}) \\
\downarrow \text { OATP1B3 IC } 500.39 \%(\mathrm{v} / \mathrm{v})\end{array}$ & \multirow[t]{5}{*}[25]{} \\
\hline & & & $\begin{array}{l}\text { GTE with atrovastatin } \\
\downarrow \text { OATP1B1 IC } 501.9 \%(\mathrm{v} / \mathrm{v}) \\
\downarrow \text { OATP1B3 IC } 501 \%(\mathrm{v} / \mathrm{v})\end{array}$ & \\
\hline & $\begin{array}{l}\text { OCT1 } \\
\text { OCT2 } \\
\text { MATE1 } \\
\text { MATE2-K } \\
\text { (Metformin) }\end{array}$ & HEK & $\begin{array}{l}\text { GTE with metformin } \\
\downarrow \text { OCT1 IC } \mathrm{C}_{50} 1.4 \%(\mathrm{v} / \mathrm{v}) \\
\downarrow \text { OCT2 IC } 507 \%(\mathrm{v} / \mathrm{v}) \\
\downarrow \text { MATE1 IC } \mathrm{C}_{50} 4.9 \%(\mathrm{v} / \mathrm{v}) \\
\leftrightarrow \text { MATE2-K }\end{array}$ & \\
\hline & \multirow[t]{3}{*}{$\begin{array}{l}\text { P-gp } \\
\text { (Digoxin) }\end{array}$} & \multirow[t]{3}{*}{ Caco-2 } & $\begin{array}{l}\text { GTE } 1 \%(v / v) \text { with digoxin } \\
\downarrow \text { P-gp } 25 \%\end{array}$ & \\
\hline & & & $\begin{array}{l}\text { EGCG } 100 \mu M \text { with BSP } \\
\downarrow \text { OATP1B1 } 36 \% \\
\downarrow \text { OATP1B3 } 88 \%\end{array}$ & \\
\hline & & & $\begin{array}{l}\text { EGCG } 100 \mu \mathrm{M} \text { with atorvastatin } \\
\downarrow \text { OATP1B1 } 31 \% \\
\downarrow \text { OATP1B3 } 57 \%\end{array}$ & continued \\
\hline
\end{tabular}




\begin{tabular}{|c|c|c|c|c|}
\hline \multirow{3}{*}{$\begin{array}{l}\text { Green tea preparation } \\
\text { and exposure }\end{array}$} & Transporter & System & Result & Reference \\
\hline & & & $\begin{array}{l}\text { EGCG } 100 \mu \mathrm{M} \text { with metformin } \\
\downarrow \text { OCT1 } 60 \% \\
\downarrow \text { OCT2 } 37 \% \\
\downarrow \text { MATE } 126 \% \\
\downarrow \text { MATE2-K } 32 \%\end{array}$ & \multirow[t]{2}{*}{ [25] } \\
\hline & & & $\begin{array}{l}\text { EGCG } 1 \mu \mathrm{M} \text { with digoxin } \\
\downarrow \text { P-gp } 50 \%\end{array}$ & \\
\hline \multirow[t]{4}{*}{$\begin{array}{l}\text { GTE } \\
\text { GTC }\end{array}$} & $\mathrm{OCT} 2$ & \multirow[t]{2}{*}{ Rat renal cortical slices } & $\begin{array}{l}\text { GTE } \\
\downarrow \text { OCT1 IC } 502.7 \mathrm{mg} / \mathrm{mL}\end{array}$ & \multirow[t]{4}{*}[26]{} \\
\hline & \multirow[t]{3}{*}{$\begin{array}{l}\text { 1-methylphenylpyridinium } \\
(\mathrm{MMP}+)\end{array}$} & & $\begin{array}{l}\text { ECG } \\
\downarrow \text { OCT1 } 1 \mathrm{I}_{50} 0.87 \mathrm{mM}\end{array}$ & \\
\hline & & \multirow[t]{2}{*}{ S2 stably expressing rat OCT2 } & $\begin{array}{l}\text { GTE } \\
\downarrow \text { OCT1 IC } 501.9 \mathrm{mg} / \mathrm{mL}\end{array}$ & \\
\hline & & & $\begin{array}{l}\text { ECG } \\
\downarrow \text { OCT1 IC } \mathrm{C}_{50} 1.67 \mathrm{mM}\end{array}$ & \\
\hline
\end{tabular}

reportedly a far more potent inhibitor than the other catechins assessed. The inhibitory constant $(\mathrm{Ki})$ values in the inhibition of CYP1A1, CYP1A2, CYP2A6, CYP2C9, CYP2E1, and CYP3A4 were $17 \mu \mathrm{M}, 10 \mu \mathrm{M}, 41 \mu \mathrm{M}, 18 \mu \mathrm{M}, 58 \mu \mathrm{M}$, and $13 \mu \mathrm{M}$, respectively [12]. Nishikawa and associates (2004) investigated the effect of a GTE, which was prepared by extraction of Chinese tea leaves with aqueous ethanol, in CYP enzyme activities using HLMs. Effects were tested on CYP2C9, CYP2D6, and CYP3A4 and it was found that all isoforms were inhibited modestly. The one-half maximal inhibitory concentration ( $\left.\mathrm{IC}_{50}\right)$ for inhibiting CYP2C9, CYP2D6, and CYP3A4 were reported as $57 \mu \mathrm{g} / \mathrm{mg}$ protein, $50 \mu \mathrm{g} / \mathrm{mg}$, and $63 \mu \mathrm{g} / \mathrm{mg}$, respectively [13]. Another study examined the effect of GTE (EFLAr942) that was obtained from Frutarom Switzerland Ltd. and EGCG that was provided from CHEMOS GmbH on the activity of CYP1A2 and CYP3A4 that was expressed in insect cell membranes. The study found that both GTE and EGCG inhibit the activity of CYP1A2 and CYP3A4 in a concentration-dependent manner. The $0.1 \mathrm{mg} / \mathrm{mL}$ of GTE and $402 \mu \mathrm{M}$ of EGCG reduced the activity of CYP1A2 by approximately $45 \%$ compared to the control (in the absence of GTE or EGCG). Moreover, $1 \mathrm{mg} / \mathrm{mL}$ GTE and $402 \mu \mathrm{M}$ of EGCG decreased the activity of CYP3A4 approximately 45 and $25 \%$, respectively [16]. The concentrations used in this study were relatively high compared to the reported concentrations of green tea catechins in humans (EGCG around 300$600 \mathrm{ng} / \mathrm{mL}$ and EGC around 550-1500 ng/mL) [42,43]

Irinotecan is a topoisomerase inhibitor used in the treatment of a number of cancers. Irinotecan is also a prodrug that is activated to its active metabolite SN-38. There are two primary detoxification pathways for irinotecan, the one for SN-38 is governed by specific UDP-glucuronosyltransferases (UGTs) to form the inactive SN-38 glucuronide, while irinotecan itself is subject to oxidative metabolism via CYP3A4 and 3A5 into the inactive metabolites APC (7-ethyl-10-[4-N-(5-aminopentanoic acid)-1-piperidino] carbonyloxycamptothecin) and NPC (7-ethyl-10-[4-(1-piperidino)-1amino] carbonyloxycamptothecin). The effect of GTCs (SigmaAldrich) on irinotecan metabolism by CYP3A4 into its inactive ox- idative metabolites was investigated. The formation of NPC in HLMs was found to be reduced by $35 \%$ or greater in the presence of EGC $10 \mu \mathrm{M}$ and was reduced more than $47 \%$ in the presence of all catechins at a concentration of $100 \mu \mathrm{M}$ [14]. In addition, a recent study assessed the influence of GTE and EGCG on CYP2B6, CYP2C8, CYP2C19, CYP2D6, and CYP3A4. In HLMs, GTE (SunphenonBG3; Taiyo) inhibited the activity of CYP2B6, CYP2C8, and CYP3A4 with $I_{50}$ values of 6,5 , and $14 \mu \mathrm{g} / \mathrm{mL}$, respectively. In addition, GTE inhibited CYP2C19 and CYP2D6 to a lesser degree with $I_{50}$ values of 49 and $25 \mu \mathrm{g} / \mathrm{mL}$, respectively. EGCG (Wako Pure Chemical Industries) likewise inhibited these enzymes to a comparable degree. The $I_{50}$ values for EGCG inhibition of CYP2B6, CYP2C8, CYP2C19, CYP2D6, and CYP3A were 8, 11, 101, 69, and $23 \mu \mathrm{M}$, respectively. In HIMs, CYP3A was inhibited and the $\mathrm{IC}_{50}$ values were $18 \mu \mathrm{g} / \mathrm{mL}$ and $31 \mu \mathrm{M}$ for GTE and EGCG, respectively [15]. Satoh and colleagues studied the inhibitory effect of eight green tea catechins on CYP1A2, CYP2C9, CYP2D6, and CYP34A enzyme activities using HLMs. All of the assessed gallated catechins inhibited the selected CYPs with the exception of CYP2D6, however, the non-gallated catechins had no inhibitory effect on any tested CYPs. Catechin gallate (CG) (Wako Pure Chemical Industries) strongly inhibited the activity of CYP2C9 with an $\mathrm{IC}_{50}$ of $7.6 \mu \mathrm{M}$, and EGCG (Nacalai Tesque) strongly inhibited the activity of CYP1A2 with an $\mathrm{IC}_{50}$ of $8.9 \mu \mathrm{M}$ [17].

\section{Metabolic induction}

There are limited in vitro data assessing potential metabolic induction by GTE or its constituents. In one study, GTE (EFLAr942; Frutarom Switzerland Ltd.) but not EGCG (CHEMOS GmbH) was shown to increase CYP1A2 mRNA expression in an LS-180 up to 7-fold. However, neither CYP1A1 nor CYP3A4 were induced by GTE or EGCG [16]. In Caco-2, GTE and EGCG both induced CYP1A1 and CYP1A2 mRNA expression in a dose-dependent approach. GTE significantly increased mRNA expression of CYP1A1 and CYP1A2 by 25- and 6-fold, respectively, and EGCG increased mRNA expression of CYP1A1 and CYP1A2 by 5- and 3-fold, re- 
- Table 3 Animal studies evaluating the effect of green tea on drug-metabolizing enzyme and transporter activity.

\begin{tabular}{|c|c|c|c|}
\hline Green tea preparation and exposure & Drug & Result & Reference \\
\hline EGCG & \multirow[t]{2}{*}{ Sunitinib } & $48 \%$ reduction in $C_{\max }$ & \multirow[t]{2}{*}{ [27] } \\
\hline$(100 \mathrm{mg} / \mathrm{kg})$ & & $52 \%$ reduction in $\mathrm{AUC}_{0-\infty}$ & \\
\hline EGCG & \multirow[t]{2}{*}{ Diltiazem } & $19-44 \%$ increase in $\mathrm{AUC}_{0-\infty}$ & \multirow[t]{2}{*}[28]{} \\
\hline$(1,4,12 \mathrm{mg} / \mathrm{kg})$ & & $43 \%$ decrease in $\mathrm{CL} / \mathrm{F}$ & \\
\hline EGCG & \multirow[t]{3}{*}{ Verapamil } & & \multirow[t]{3}{*}{ [29] } \\
\hline $2 \mathrm{mg} / \mathrm{kg}$ & & $52 \%$ increase in $\mathrm{AUC}_{0-\infty}$ & \\
\hline $10 \mathrm{mg} / \mathrm{kg}$ & & $87 \%$ increase in $\mathrm{AUC}_{0-\infty}$ & \\
\hline EGCG & \multirow[t]{4}{*}{ Nicardipine } & & \multirow[t]{4}{*}[30]{} \\
\hline $0.5 \mathrm{mg} / \mathrm{kg}$ & & $19 \%$ increase in $\mathrm{AUC}_{0-\infty}$ & \\
\hline $3 \mathrm{mg} / \mathrm{kg}$ & & $56 \%$ increase in $\mathrm{AUC}_{0-\infty}$ & \\
\hline $10 \mathrm{mg} / \mathrm{kg}$ & & $88 \%$ increase in $\mathrm{AUC}_{0-\infty}$ & \\
\hline Green tea & \multirow[t]{2}{*}{ 5-Fluorouracil } & $151 \%$ increase in $C_{\max }$ & \multirow[t]{2}{*}[31]{} \\
\hline$(50 \mathrm{mg} / \mathrm{kg})$ & & $524 \%$ increase in $\mathrm{AUC}_{0-\infty}$ & \\
\hline Green tea & \multirow[t]{2}{*}{ Clozapine } & $43 \%$ increase in $C_{\max }$ & \multirow[t]{2}{*}[32]{} \\
\hline $175 \mathrm{mg} / \mathrm{kg}$ & & $50 \%$ increase in $\mathrm{AUC}_{0-\infty}$ & \\
\hline EGCG & \multirow[t]{4}{*}{ Tamoxifen } & & \multirow[t]{4}{*}{ [33] } \\
\hline $0.5 \mathrm{mg} / \mathrm{kg}$ & & $15 \%$ increase in $\mathrm{AUC}_{0-\infty}$ & \\
\hline $3 \mathrm{mg} / \mathrm{kg}$ & & $32 \%$ increase in $\mathrm{AUC}_{0-\infty}$ & \\
\hline $10 \mathrm{mg} / \mathrm{kg}$ & & $43 \%$ increase in $\mathrm{AUC}_{0-\infty}$ & \\
\hline Green tea & \multirow[t]{4}{*}{ Nadolol } & $85 \%$ decrease in $C_{\max }$ & \multirow[t]{4}{*}[34]{} \\
\hline$(400 \mathrm{mg} / \mathrm{kg})$ & & $74 \%$ decrease in $A \cup C_{0-\infty}$ & \\
\hline EGCG & & $80 \%$ decrease in $C_{\max }$ & \\
\hline$(100 \mathrm{mg} / \mathrm{kg})$ & & $73 \%$ decrease in $A \cup C_{0-\infty}$ & \\
\hline GTE & \multirow[t]{2}{*}{ Simvastatin } & $230 \%$ increase in $C_{\max }$ & \multirow[t]{2}{*}{ [35] } \\
\hline$(400 \mathrm{mg} / \mathrm{kg})$ & & $242 \%$ increase in $\mathrm{AUC}_{0-6}$ & \\
\hline GTE & \multirow[t]{2}{*}{ Quetiapine } & $34 \%$ decrease in $C_{\max }$ & \multirow[t]{2}{*}[36]{} \\
\hline $175 \mathrm{mg} / \mathrm{kg}$ & & $35 \%$ decrease in $A \cup C_{0-\infty}$ & \\
\hline
\end{tabular}

spectively [16]. In contrast to the aforementioned study, Mirkov and colleagues (2006) investigated the influence of green tea catechins (Sigma-Aldrich) on CYP3A4 activity using human hepatocytes and reported that neither EGCG, ECG nor EGC induced CYP3A4 activity [14].

\section{Uridine 5'-diphospho-glucuronosyltransferase enzyme}

Uridine 5'-diphospho-glucuronosyltransferase enzyme inhibition

Drug metabolism by phase II enzymes mainly occurs via conjugation with glucuronic acid (glucuronidation) and to a lesser degree through sulphation, methylation, and glutathione conjugation [44]. The UGTs are a superfamily of 18 different enzymes involved in the metabolism of almost $10 \%$ of the top 200 prescribed drugs [45]. The glucuronidation of EGCG and EGC were investigated using HLM and UTG expressed isozymes. EGCG was determined to be glucuronidated predominantly by UGT1A1, 1A8, and 1A9 [46]. Irinotecan is largely metabolized by UGT1A1 to 7-ethyl-10hydroxycamptothecin glucuronide (SN-38G) [47]. Green tea cate- chins (Sigma-Aldrich) were found to decrease the formation of SN-38G in HLMs due to the inhibition of UGT1A1 activity. Among the green tea catechins, ECG and EGCG have produced the highest degree of inhibition of SN-38G formation. A concentration of $100 \mu \mathrm{M}$ of both ECG and EGCG produced more than $80 \%$ inhibition of SN-38G formation compared to the control [14]. Mohamed and coworkers [19] also reported that EGCG (SigmaAldrich) inhibited the activity of UGT1A1 in HLMs with a reported $\mathrm{IC}_{50}$ of $17 \mu \mathrm{M}$. Mohamed and Frye [18] assessed the effect of EGCG (Sigma-Aldrich) on UGT1A4, 1A6, and 1A9 using HLMs. EGCG was found to inhibit UGT1A4 with an $\mathrm{IC}_{50}$ value of $74 \mu \mathrm{M}$.

\section{Uridine $5^{\prime}$-diphospho-glucuronosyltransferase} enzyme induction

Few studies have evaluated the potential induction of UGT enzymes by green tea or its constituents. However, at least one study has assessed the effect of the green tea catechins EGCG, ECG, and EGC (Sigma-Aldrich) on irinotecan glucuronidation via UGT1A1 in human hepatocytes. Mirkov and coworkers reported that EGCG, ECG, and EGC at $2 \mu \mathrm{M}$ slightly increased the pro- 
- Table 4 Clinical studies evaluating the effect of green tea on drug-metabolizing enzyme and transporter activity.

\begin{tabular}{|c|c|c|c|}
\hline $\begin{array}{l}\text { Green tea preparation and } \\
\text { exposure }\end{array}$ & Drug & Result & Reference \\
\hline \multirow[t]{2}{*}{ EGCG (800 mg/day) } & $\begin{array}{l}\text { Caffeine (CYP1A2) } \\
\text { Dextromethorphan (CYP2D6) }\end{array}$ & $\begin{array}{l}\text { No significant effect on CYP1A2 or CYP2D6 } \\
\text { or CYP2C9 activity }\end{array}$ & \multirow[t]{2}{*}{ [37] } \\
\hline & $\begin{array}{l}\text { Losartan (CYP2C9) } \\
\text { Buspirone (CYP3A) }\end{array}$ & $\begin{array}{l}\text { Minor decrease in CYP3A4 activity } \\
\text { ( } 20 \% \text { increase in AUC) }\end{array}$ & \\
\hline $\begin{array}{l}\text { Decaffeinated GTE } \\
\text { ( } 211 \mathrm{mg} \text { of catechins) }\end{array}$ & $\begin{array}{l}\text { Dextromethorphan (CYP2D6) Alprazolam } \\
\text { (CYP3A4) }\end{array}$ & No significant effect on CYP2D6 or CYP3A4 & [38] \\
\hline EGCG & \multirow[t]{3}{*}{ Iron isotopes $\left({ }^{57} \mathrm{Fe}\right)$} & Minor reduction on Iron absorption & \multirow[t]{3}{*}{ [39] } \\
\hline (150 mg/day) & & $15 \%$ & \\
\hline (300 mg/day) & & $27 \%$ & \\
\hline \multirow[t]{2}{*}{ GTE $(0.3 \mathrm{~g} / 250 \mathrm{~mL})$} & Folic acid (0.4 mg) & $\begin{array}{l}39 \% \text { decrease } C_{\max } \\
27 \% \text { decrease } A \cup C_{0-\infty}\end{array}$ & \multirow[t]{2}{*}{ [40] } \\
\hline & Folic acid (5 mg) & $\begin{array}{l}27 \% \text { decrease } C_{\max } \\
40 \% \text { decrease } A \cup C_{0-\infty}\end{array}$ & \\
\hline \multirow[t]{3}{*}{ Green tea (700 mL/day) } & \multirow[t]{3}{*}{ Nadolol (OATP1A2) } & Inhibition of OATP1A2 uptake & \multirow[t]{3}{*}{ [22] } \\
\hline & & $85 \%$ decrease $C_{\max }$ & \\
\hline & & $85 \%$ decrease $\mathrm{AUC}_{0-48}$ & \\
\hline
\end{tabular}

duction of SN-38G by $60-160,40-130$, and $50-80 \%$, respectively, relative to the study control. However, in a Hep $\mathrm{G} 2$ cell culture, the selected catechins were found to have no influence on the formation of the irinotecan metabolite SN-38G. Moreover, the level of UGT1A1 mRNA that was expressed in human hepatocytes was not significantly increased [14].

\section{Drug transporters}

Although the majority of the published drug-botanical interaction studies focus on the inhibition of DMEs, the role of drug transporters in these interactions is of increasing interest to the field and a number of studies have been published ( $\bullet$ Table 2 ). A study utilizing HEK 293 cells stably expressing OATP B transporter (OATP-B) tested the effect of groups of botanical extracts and phytochemicals on the function of this transporter, which is expressed on intestinal epithelial cells and plays a role in the absorption of many drugs [20]. The study indicated that GTE (Tokiwa Phytochemical Co.) and EGCG (Extrasynthese S. A.) potently inhibit the uptake of the prototypical substrate estrone-3-sulfate by 82 and $75 \%$, respectively, compared to a control [20]. Another in vitro study examined the effect of the green tea catechins, ECG, and EGCG (Sigma-Aldrich) on the uptake function of OATP1A2, OATP1B1, OATP1B3, and OATP2B1 present in human enterocytes and hepatocytes. Estrone-3-sulfate served as the model substrate for all tested transporters and the uptake was measured in the presence and absence of catechins. Human OATP1B1, OATP1B3, and OATP2B1 were transfected into $\mathrm{CHO}$ cells and OATP1A2 was expressed in HEK-293 cells. ECG was found to inhibit the uptake capacity of OATP1A2, OATP1B1, and OATP2B1 with IC 50 values of 10,59 , and $36 \mu \mathrm{M}$, respectively, while the constituent EGCG was found to inhibit the uptake ability of OATP1A2, OATP1B1, and OATP2B1 with $\mathrm{IC}_{50}$ values of 55,8 , and $101 \mu \mathrm{M}$, respectively. On the other hand, EGCG at concentrations ranging between 30-
$300 \mu \mathrm{M}$ strongly induced the uptake of estrone-3-sulfate by OATP1B3 by 5-fold, however, the uptake of estradiol-17B-glucuroinde by OATP1B3 was unaffected [21].

A further in vitro study investigated the influence of GTE (EFLAr942; Frutarom Switzerland Ltd.) and its primary catechin EGCG (CHEMOS GmbH) on the mRNA expression level of P-gp and multidrug resistance associate protein 2 (MRP2) in human gastrointestinal epithelial LS-180 cells. The mRNA expression of P-gP and MRP2 were not changed by GTE at $0.01 \mathrm{mg} / \mathrm{mL}$. However, it was noted that GTE at $1 \mathrm{mg} / \mathrm{mL}$, but not EGCG, inhibited MRP2 activity and therefore increased the methotrexate permeability by almost 2-fold [23]. The effect of GTPs and EGCG on $\mathrm{P}$-gP was also studied in a $\mathrm{CHO}$ cell line (CHRC5). GTPs were from LKT Laboratories and EGCG was from Sigma-Aldrich. GTPs at a concentration of $10 \mu \mathrm{g} / \mathrm{ml}$ reduced P-gp photolabeling by $50 \%$. The accumulation of R-123 was increased by 2.2- and 8.3-fold at concentrations of $15 \mu \mathrm{g} / \mathrm{mL}$ and $300 \mu \mathrm{g} / \mathrm{mL}$, respectively. In addition, EGCG was found to inhibit P-gp and increased the accumulation of R-123 by almost 4-fold at a concentration of $100 \mu \mathrm{M}$ [24]. The concentrations of GTPs and EGCG that resulted in the inhibition on P-gp in this study were quite high and likely beyond those that would be achieved in humans receiving even high doses of GTPs or GTE.

In addition, a recent in vitro study found that GTE (Healthya green tea) and EGCG (University of Shizuoka, Japan) inhibited the uptake efficiency of OATP1B1, OATP1B3, organic cation transporter $(\mathrm{OCT}) 1$, and OCT2 as well as the multidrug and toxin extrusion (MATE)1 and MATE2-K transporters, and the P-gP efflux transporter. Uptake of the substrate bromosulphophthalein (BSP) by OATP1B1 and OATP1B3 in a human embryonic kidney (HEK) cell line was inhibited by GTE with $\mathrm{IC}_{50} \mathrm{~S}$ of $2.6 \%(\mathrm{v} / \mathrm{v})$ and $0.39 \%$ $(v / v)$, respectively. Moreover, the uptake of BSP by OATP1B1 and OATP1B3 was reduced by EGCG to 64 and 12\%, respectively, of 
net uptake values in the absence of EGCG. The uptake of another known OATP substrate, atorvastatin, by OATP1B1 and OATP1B3 was inhibited by GTE with $\mathrm{IC}_{50} \mathrm{~S}$ of $1.9 \%(\mathrm{v} / \mathrm{v})$ and $1 \%(\mathrm{v} / \mathrm{v})$, respectively. The uptake of atorvastatin by OATP1B1 and OATP1B3 was reduced by EGCG to 64 and $43 \%$, respectively, of the net uptake in the absence of EGCG. The uptake of the known substrate metformin in HEK transfected cells by OCT1, OTC2, and MATE1 was inhibited significantly by GTE with IC 50 values of $1.4(\mathrm{v} / \mathrm{v}), 7.0(\mathrm{v} /$ $\mathrm{v})$, and $4.9 \%(\mathrm{v} / \mathrm{v})$, respectively. The reduction of OCT1, OTC2, MATE1, and MATE2-K uptake was inhibited by EGCG to 60, 37, 26 , and $32 \%$ of that of the control, respectively. In a human Caco- 2 cell line, the transport of the P-gp substrate digoxin was reduced significantly in the presence of GTE and EGCG by 25 and $50 \%$, respectively [25]. A recent study has evaluated the influence of GTE (Thai Tea Suwirun Company) and green tea catechins on renal basolateral organic cation transporter 2 (OCT2) using rat renal cortical slices and S2 stably expressing rat OCT2. The GTE and ECG (Wako Pure Chemical Industries, Ltd.) both inhibited the uptake of 1-methyl phenylpyridinium (MMP+) in a concentrationdependent manner in renal slices with $\mathrm{IC}_{50} \mathrm{~s}$ of $2.7 \mathrm{mg} / \mathrm{mL}$ and $0.87 \mathrm{mM}$, respectively. However, other catechins did not inhibit the uptake of MMP+. In addition, the activity of OCT2 in the S2 stably expressed OCT2 was inhibited only by GTE and ECG with the $\mathrm{IC}_{50}$ of $\left[{ }^{3} \mathrm{H}\right] \mathrm{MPP}+1.9 \mathrm{mg} / \mathrm{mL}$ and $1.67 \mathrm{mM}$ [26].

In summary, a substantial number of in vitro studies have been carried out that have utilized a variety of assay methods and evaluated a number of differently sourced green tea extracts. The majority of which suggest that GTE or its components may significantly inhibit one or more CYP enzymes ( $\triangleright$ Table 1). Among the CYP enzymes assessed, CYP1A2 and CYP3A4 were reportedly inhibited by GTE, EGC, and EGCG. The CYP2B6, CYP2C8, and CYP2C9 enzymes were inhibited by both GTE and EGCG. The CYP2D6 enzyme was inhibited only by GTE, and CYP2E1 was inhibited only by EGCG. Few studies evaluated the induction of CYP enzymes by GTE and EGCG. CYP1A1 and CYP1A2 were both induced by GTE and EGCG. With regard to UGT enzymes, EGCG was found to inhibit UGT1A1 and UGT1A4 and at low concentrations, EGCG, ECG, and EGC were found to induce UGT1A1 ( $\triangleright$ Table 1). Regarding drug transporters, GTE and EGCG were reported to inhibit the efflux transporters P-gp, MRP, and MATE ( $\vee$ Table 2 ). Furthermore, transporters OATP-A, OATP-B, OCT1, and OCT2 uptake efficiencies were inhibited by GTE and EGCG in in vitro studies. Additionally, the influx transporter OATP1B3 was induced by EGCG [12-26].

\section{Interaction assessments using animal models}

The use of animal models in research on drug interactions is not uncommon, but of limited utility due to a variety of factors, not the least of which are interspecies differences in metabolism, dosing, and response that can severely limit the predictive value of the results obtained [41]. Nevertheless, a number of studies using rodents have investigated the impact of administering GTE or specific green tea constituents on the pharmacokinetics of clinically prescribed medications and are highlighted in $>$ Table 3. Sunitinib, an orally administered tyrosine kinase inhibitor used to treat metastatic renal cell carcinoma and advanced gastrointestinal stromal tumor patients, and EGCG (Sigma-Aldrich) were directly administrated into the stomach (by gastric gavage) of male Sprague-Dawley rats. The doses of sunitinib and EGCG (both were dissolved in water) were $30 \mathrm{mg} / \mathrm{kg}$ and $100 \mathrm{mg} / \mathrm{kg}$, respectively. The $C_{\max }$ and the area under the plasma concentration-time curve (AUC) extrapolated to infinity $\left(\mathrm{AUC}_{0_{-} \infty}\right)$ of sunitinib plasma, after ingesting EGCG, were reduced by 48 and $52 \%$, respectively [27].

Another investigation assessed the influence of different EGCG (Sigma-Aldrich) doses $(1,4,12 \mathrm{mg} / \mathrm{kg}$ ) administrated orally on the pharmacokinetics of orally $(12 \mathrm{mg} / \mathrm{kg})$ and intravenous $(5 \mathrm{mg} / \mathrm{kg}$ ) diltiazem, a calcium channel blocker (CCB), and its primary active metabolite, desacetyldiltiazem, whose formation is mediated through CYP3A4 in humans. Further, both compounds are substrates of $\mathrm{P}$-gp. The study was conducted in male SpragueDawley rats and the oral doses of EGCG and diltiazem (both were dissolved in water) were given by gavage, while the intravenous dose of diltiazem (was dissolved in $0.9 \% \mathrm{NaCl}$ ) was given through the femoral vein. The peak concentration $\left(C_{\max }\right)$ and the AUC of diltiazem increased significantly when administered concurrently with EGCG. In addition, the increase of $C_{\max }$ and AUC of diltiazem was associated with the increase of the EGCG dose. The AUC of oral diltiazem increased from 19 to $44 \%$ depending on the doses of EGCG administered, and increased $80 \%$ after intravenous dosing. The total clearance (CL/F) decreased by $43 \%$ when EGCG was coadministrated with diltiazem. The desacetyldiltiazem-diltiazem AUC ratio decreased to a non-significant degree; therefore, it was suggested the EGCG may increase the $C_{\max }$ and AUC of diltiazem via inhibition of CYP3A4-mediated metabolism and P-gp-mediated efflux in the intestine [28].

Verapamil, also a CCB, is an antihypertensive and antiarrhythmic agent extensively metabolized in the liver by CYP3A4 to norverapamil. In addition, verapamil is known to be a P-gp substrate. A study was conducted in Sprague-Dawley rats to evaluate the effect of EGCG (Sigma-Aldrich) on $9 \mathrm{mg} / \mathrm{kg}$ verapamil pharmacokinetics (both were dissolved in water). The $2-\mathrm{mg} / \mathrm{kg}$ dose of EGCG increased the AUC by $52 \%$ and the $10-\mathrm{mg} / \mathrm{kg}$ dose increased the AUC by $87 \%$ compared with the controls. Since the AUC of verapamil and norverapamil both increased in the presence of EGCG, the inhibition seemed to be on P-gp [29]. In addition to verapamil, nicardipine, another $C C B$, was coadministrated with EGCG (Sigma-Aldrich) in male Sprague-Dawley rats (both were dissolved in water) to assess the effect of EGCG on CYP3A4 and intestinal P-gp. The coadministration of $0.5,3$, and $10 \mathrm{mg} / \mathrm{kg}$ EGCG increased the AUC of orally administered nicardipine (12 kg/ $\mathrm{ml}$ ) by 19,56 , and $88 \%$, respectively. Nevertheless, EGCG did not significantly increase the AUC of intravenously administered nicardipine $(4 \mathrm{mg} / \mathrm{kg})$. These results, according to the investigators, suggest that EGCG inhibited both hepatic CYP3A and intestinal P-gp [30].

Green tea is frequently consumed by patients undergoing chemotherapeutic regimens for cancer [48]. However, there are only a limited number of studies on the effect of the coadministration of green tea with anticancer drugs. To investigate the potential effects of consuming GTE (Lipton green tea) on the pharmacokinetics of 5-fluorouracil (5-FU), Qiao et al. studied the effect of orally administered green tea dissolved in water $(50 \mathrm{mg} / \mathrm{kg})$ on the pharmacokinetics of a single intraperitoneal injection of 5-FU $(48 \mathrm{mg} / \mathrm{kg})$ in male Sprague-Dawley rats. The study found the 
AUC of 5 -FU increased by $524 \%$ and the $C_{\max }$ increased by $151 \%$ in the green tea-treated group compared with the controls. The investigators suggested that patients habitually drinking green tea might be candidates for therapeutic drug monitoring if it were consumed concurrently with 5-FU [31].

The effect of GTE (Exolise Alkopharma) administration on the pharmacokinetics of clozapine was studied in male SpragueDawley rats. Clozapine, an atypical antipsychotic drug, is predominantly metabolized via CYP1A2 to its primary metabolite $\mathrm{N}$-desmethylclozapine in humans. Doses of $175 \mathrm{mg} / \mathrm{kg}$ of GTE (containing $22 \mathrm{mg}$ of EGCG and $9 \mathrm{mg}$ of caffeine) were given through an intragastric tube with clozapine $20 \mathrm{mg} / \mathrm{kg}$. The $C_{\max }$ and $A \cup C_{0-\infty}$ of clozapine were reduced after coadministration with GTE by 43 and $50 \%$, respectively. The reduction in both $C_{\max }$ and AUC suggested potential interactions during the absorption and metabolism phases, however, the authors indicated that they could not exclude the potential influence of GTE on drug transporters [32]. Additionally, it is noted that the GTE utilized contained modest amounts of caffeine, another recognized CYP1A2 substrate that has been shown to elevate clozapine concentrations in humans, which may further cloud the interpretation of these results [49].

The influence of EGCG on the pharmacokinetics and bioavailability of tamoxifen was also examined in male Sprague-Dawley rats. Tamoxifen is an estrogen modulator metabolized to active metabolites, 4-hydroxytamoxifen and $\mathrm{N}$-desmethyltamoxifen, catalyzed by CYP2D6 and CYP3A4. In addition, tamoxifen is a recognized substrate of P-gp. A $10-\mathrm{mg} / \mathrm{kg}$ dose of tamoxifen with and without $0.5,3$, and $10 \mathrm{mg} / \mathrm{kg}$ of EGCG (Sigma-Aldrich) were administered intragastrically through a feeding tube and both were dissolved in water. The mean plasma concentration time profiles of tamoxifen significantly increased after exposure to the 3 and $10 \mathrm{mg} / \mathrm{kg}$ doses of EGCG. Indeed, in the presence of EGCG $(3 \mathrm{mg} / \mathrm{kg})$, the $C_{\max }$ and $A U C_{0-\infty}$ of tamoxifen increased by 36 and $32 \%$, respectively. Furthermore, a higher dose of EGCG $(10 \mathrm{mg} /$ $\mathrm{kg}$ ) resulted in a larger magnitude of increase in $C_{\max }$ and $\mathrm{AUC}_{0-\infty}$ of tamoxifen (i.e., 47 and $43 \%$, respectively). Therefore, elevated tamoxifen plasma concentrations following EGCG coadministration could be due to the enhancement of intestinal absorption and reduction of first-pass metabolism [33]. Misaka and colleagues investigated the effect of GTE (SunphenonBG3; Taiyu Kagaku Co., Ltd.) on the pharmacokinetics of simvastatin in female Sprague-Dawley rats. Simvastatin, a lipid-lowering prodrug, is metabolized by CYP3A to its active metabolite, simvastatin acid. In this investigation, rodents were administrated a single dose of GTE $(400 \mathrm{mg} / \mathrm{kg})$ that was dissolved in water and simvastatin $(20 \mathrm{mg} / \mathrm{kg})$ that was dissolved in $0.5 \%$ carboxymethylcellulose via oral gavage. The $\mathrm{AUC}_{0-6}$ and $\mathrm{C}_{\max }$ were increased 3.4-fold and 3.3-fold, respectively, compared to the control condition. It was speculated by the investigators that the change in the simvastatin pharmacokinetics may have been the result of GTE inhibition of intestinal CYP3A activity [35]. In addition, Misaka et al. (2013) investigated the effect of GTE (SunphenonBG3) and EGCG (University of Shizuoka, Japan) on the pharmacokinetics of nadolol in male Sprague-Dawley rats. Nadolol, a non-selective beta-blocker, is not a substrate of CYP enzymes, but is a substrate for efflux and uptake transporters, primarily P-gp and OATP1A2. The animals received a single dose of GTE ( $400 \mathrm{mg} / \mathrm{kg}$, dissolved in saline) or EGCG $(150 \mathrm{mg} / \mathrm{kg}$, dissolved in saline) via oral gavage, followed by a single intragastric dose of nadolol $(10 \mathrm{mg} / \mathrm{kg}$, dissolved in water). The nadolol $C_{\max }$ and $A U C$ were reduced by 85 and $74 \%$, respectively. Moreover, the $\mathrm{C}_{\max }$ and $\mathrm{AUC}_{0-\infty}$ of nadolol after the EGCG pretreatment were reduced by 80 and $73 \%$, respectively. This study did not elucidate the mechanism(s) leading to the reduction of nadolol plasma concentrations, but the authors speculated that it might have been due EGCG-mediated inhibition of uptake transporter activity [34].

The effect GTE on the pharmacokinetics of quetiapine was investigated in Wistar Albino rats. Quetiapine is an atypical antipsychotic and partial CYP3A4 substrate. The animals were administered $175 \mathrm{mg} / \mathrm{kg}$ of GTE (General Nutrition Corporation) for 7 days by oral gavage and then a single $25 \mathrm{mg} / \mathrm{kg}$ dose of quetiapine was administered intragastrically. The $C_{\max }$ and $A U C$ of quetiapine were significantly reduced by more than $30 \%$. Since the half-life and the elimination rate remained unchanged, the authors suggested a potential influence on the absorption of quetiapine [36].

Although animal studies have a number of recognized translational limitations, they are still valuable sources of data, and a number of published reports suggest that GTE or its associated catechins, particularly EGCG, inhibit the activity of few CYP enzymes ( $\triangleright$ Table 3 ). The values of $C_{\max }$ and AUC of CYP3A and P-gp substrates, diltiazem, verapamil, tamoxifen, simvastatin, and nicardipine were increased after rats were exposed to EGCG, suggesting that EGCG might inhibit CYP3A and/or P-gp activities [28-30, 33, 35]. However, the $C_{\max }$ and AUC of other CYP3A4 substrates (e.g., quetiapine, sunitinib) were reduced in rats administered GTE or EGCG $[27,36]$. GTE decreased the $C_{\max }$ and AUC of clozapine in rats, ostensibly due to the metabolic induction of CYP1A2 [32]. Additionally, nadolol plasma concentrations were deceased in rats after pretreatment with GTE and EGCG, possibly through inhibition of intestinal OATP transporters [34].

\section{Clinical studies}

Formal controlled clinical studies provide the most rigorous assessment of botanical-drug interaction potential. However, these studies are infrequently performed due to their considerable expense and the resource-intensive nature of the study methodology. Standard methodologies for assessing the potential for pharmacokinetic drug-drug interactions typically involve the use of healthy non-medicated research subjects who are administered one or more "probe" drug substrate medications that are known to be predominantly metabolized or transported by a specific enzyme or drug transporter, respectively. Patients typically receive the probe medications (representing the potential "victim" drug) on two occasions, once alone, and a second time concurrently with the suspected "perpetrator" agent (e.g., GTE). On both occasions serial blood concentrations are measured to enable investigators to determine if the suspected offending agent exerted any influence on the disposition of the respective probe drug [50]. Formal clinical studies are highlighted in > Table 4.

Chow and associates (2006) conducted a clinical study to assess the influence of repeated green tea catechin administration on human CYP enzyme activity. The study included 42 healthy participants who received a combination or "cocktail" of common probe substrates for the major CYP enzymes of interest at base- 
line and after a 4-week exposure to green tea (Polyphenon E), a proprietary green tea extract (containing $200 \mathrm{mg}$ of EGCG and small quantities of caffeine, $0.5 \% \mathrm{w} / \mathrm{w}$ per capsule). Subjects were instructed to take four capsules daily.

The probe drug substrates included caffeine for CYP1A2, dextromethorphan for CYP2D6, losartan for CYP2C9, and buspirone for CYP3A4. The authors reported that the GTE did not significantly influence the activity of any of the assessed enzymes. However, a minor decrease in CYP3A4 activity was noted, which resulted in a $20 \%$ increase in the area under the plasma AUC of buspirone [37]. Thus, it does not appear likely that green tea exposure significantly affects the disposition of drugs metabolized by these CYP enzymes. It is notable that this study design incorporated a one-day gap between the administration of the last dose of GTE and receiving the probe drug cocktail. This delay may have permitted GTE catechins to be cleared from the human body prior to exerting maximal inhibitory influences.

In a study conducted by Donovan and coworkers (2004), the effects of an orally administered decaffeinated GTE product (Decaffeinated Super Green Tea Extract; Life Extension) on the activity of the DMEs CYP2D6 and CYP3A4 was determined. Eleven healthy volunteers ingested two capsules of a decaffeinated GTE formulation containing $211 \mathrm{mg}$ of catechins twice daily for 14 days. Dextromethorphan and alprazolam were utilized as substrates for CYP2D6 and CYP3A4, respectively, and the plasma concentrations of both were compared before and after the GTE dosing. The study reported that GTE exposure did not appreciably affect the pharmacokinetic profile of dextromethorphan or alprazolam. Therefore, it was concluded that modest GTE consumption was unlikely to alter the disposition of medications significantly metabolized by CYP2D6 and CYP3A4 [38].

In a recently published study, the effect of green tea on the pharmacokinetics parameters of nadolol, a beta-blocker drug that's used in the treatment of hypertension and angina pectoris, was investigated [22]. A single 30-mg oral nadolol dose was given to 10 healthy participants after a 14-day pretreatment period with $700 \mathrm{~mL} /$ day of green tea (Healthya green tea; Kao Corporation) or water. The green tea catechin content was not specified in the study. The $C_{\max }$ and $A \cup C_{0-48}$ of nadolol were both significantly decreased $(p<0.01)$ by $85 \%$. In the same study, after confirming that nadolol was a substrate of OATP1A2, they investigated the influence of green tea on OATP1A2 using HEK293 cells. The results from the in vitro study demonstrated that green tea significantly inhibited OATP1A2-mediated nadolol uptake. Therefore, the reduction of the plasma concentrations of nadolol after concomitant use with green tea could be, in part, due to the inhibition of intestinal OATP1A2 uptake [22]. Ide and colleagues (2014) took issue with the type of green tea beverage utilized in the study, suggesting it was an uncommon type of tea beverage and classified as a food for specified health use in Japan and was not typical of green tea beverages commonly consumed for refreshment [51]. The concentration of catechin of the product was high $(1.54 \mathrm{mg} / \mathrm{mL})$ compared to other common green tea products $(0.25-0.51 \mathrm{mg} / \mathrm{mL})[51,52]$. Nevertheless, the clinical study did demonstrate a significant effect of a green tea beverage on nadolol disposition.
In a randomized, double-blind, placebo-controlled, crossover study, the effect of EGCG on iron absorption was assessed in 30 otherwise healthy women with low iron stores. The study consisted of 3 treatment phases including placebo, $150 \mathrm{mg}$, or 300 mg EGCG (Teavigo Taiyo Kagaku Co., Ltd.) for 8 days with a washout period of 14 days. Iron isotopes were administered orally $\left({ }^{57} \mathrm{Fe}\right)$ and intravenously $\left({ }^{58} \mathrm{Fe}\right)$ during the last 5 days of the active treatment phase. The study results indicated a reduction in iron absorption after exposure to EGCG $150 \mathrm{mg}$ and $300 \mathrm{mg}$ by 14 and $27 \%$, respectively, compared to placebo. The investigators concluded that the degree of reduced iron absorption associated with EGCG supplementation was not clinically significant [39].

In an open-labeled, randomized, crossover study, the potential interaction between green tea and black tea with folic acid supplementation was investigated. In this somewhat complicated design, seven healthy participants received five different exposures (i.e., A, B, C, D, E) separated by a one-week washout period and exposures $A$ and $B$ occurred twice. Exposure A consisted of $0.4 \mathrm{mg}$ folic acid taken with green tea; Exposure B consisted of $0.4 \mathrm{mg}$ folic acid taken with black tea; Exposure C: consisted of $0.4 \mathrm{mg}$ folic acid taken with water; Exposure D: consisted of $5 \mathrm{mg}$ of folic acid taken with water; and Exposure E which consisted of $5 \mathrm{mg}$ of folic acid taken with green tea).

Spray-dried green tea powdered extracts of green or black tea (Plantextrak) were used to prepare the study tea beverages, which were administered at a concentration of $0.3 \mathrm{~g} / 250 \mathrm{~mL}$. The EGCG content was reported as $207 \mu \mathrm{mol} / \mathrm{g}$ in the green tea and $4.4 \mu \mathrm{mol} / \mathrm{g}$ in the black tea. Blood samples were collected over a period of $8 \mathrm{~h}$.

The study results indicated that at the $0.4-\mathrm{mg}$ folic acid dose, green and black tea exposures reduced the mean $C_{\max }$ of serum folate by 39.2 and $38.6 \%$, respectively. Additionally, both green and black tea exposures reduced the mean $A_{U} C_{0-\infty}$ by 26.6 and $17.9 \%$, respectively. At the $5-\mathrm{mg}$ folic acid dose, the mean $C_{\max }$ of serum folate was reduced by $27.4 \%$ and the mean $A U C_{0-\infty}$ was decreased by $39.9 \%$ during the concurrent exposure to green tea. In summary, it appears that modest consumption of green or black tea may significantly decrease the bioavailability of folic acid supplements if administered concomitantly. The authors speculate on several mechanisms that might explain the influence of tea including inhibition of carrier-mediated absorption of folates in the small intestine or involvement of efflux transporters. In any case, these findings may be of clinical significance in certain patients being treated for a folate deficiency who are regular consumers of high amounts of tea or tea catechins on a daily basis [40].

To date, only a few clinical pharmacokinetic studies have been conducted in human subjects. Of two available studies utilizing a probe drug approach, it appears that the activities of CYP1A2, CYP2D6, CYP2C9, and CYP3A4 enzymes are unlikely to be significantly influenced by modest GTE exposure $[37,50]$. This finding is generally at odds with in vitro reports, which suggested metabolic inhibition, but the disparate findings of in vitro vs. in vivo studies is not an uncommon finding in the field of botanical-drug interaction assessment [41]. An additional study assessed the influence of a green tea beverage on the pharmacokinetics of a single 30 -mg dose of nadolol and reported very significant reductions in 
the $C_{\max }$ and $\mathrm{AUC}_{0-48}$. The authors speculated that the likely mechanism for the interaction was the inhibition of OATP1A2-mediated nadolol uptake [22]. In two other clinical studies not assessing specific metabolic routes or transporters, a proprietary EGCG formulation was found to have no effect on iron absorption, while a GTE formulation resulted in reduced bioavailability of coadministered folic acid $[39,40]$.

It should be emphasized that the results of the clinical studies assessing GTE or specific catechins cannot be generalized to all botanical supplements or extracts, which can differ considerably in phytochemical content. Also, note that each of the studies discussed above utilized a different green tea/catechin formulation in their interaction assessment.

\section{Conclusions}

GTE and one or more of its associated catechins have been evaluated in a number of in vitro animal and clinical studies for their potential to modulate selected DMEs and drug transporters. These studies were generally conducted by independent laboratories or research programs, employed a variety of different study paradigms, assay conditions, and substrates, and assessed an array of concentrations of whole extracts and singular green tea components (e.g., EGCG). Furthermore, reviewed studies utilized GTEs and catechins sourced from an array of manufacturers. As a result, only limited conclusions may be drawn, which cannot be generalized to all green tea products.

In almost every instance in which an interaction or potential interaction was suggested by an in vitro or animal study, the results were not observed in clinical studies that have been conducted, which should have revealed them. Such discrepancies between in vitro studies of drug interactions with botanical extracts/constituents and results from clinical studies are not uncommon. These differences likely occur for a multitude of reasons, including the use of higher concentrations used to inhibit the P450 enzymes in vitro than physiologically attainable concentrations in man. There are inherent difficulties accounting for bioavailability, distribution, first-pass metabolism, and active metabolites of botanical constituents in man [41]. The in vivo concentration of a suspected inhibitor at an active or site is generally estimated and unknown in in vitro experiments and typically based upon available pharmacokinetic values when these are known, which is often not the case for botanical supplements. When these values are known, the assumption is that it is the plasma concentration presented to hepatocytes and CYP or other enzymes or transporters, which may also be inaccurate. Additionally, variability in the chemical composition of commercially available botanical supplements and the lack of analytical standards in some cases may contribute to the discrepancies.

In conclusion, GTE and its principal catechins, at modest consumption levels, generally appear unlikely to result in clinically significant effects on the disposition of drugs metabolized by CYP and/or UGT enzymes and do not appear to influence the fate of medications serving as substrates for the P-gp transporter. At least one small clinical study suggests that relatively modest tea consumption concurrently with folic acid may significantly reduce the bioavailability of folic acid. However, the mechanism of this effect is unclear. The disposition of drugs that are substrates of OATP transporters might be influenced by significant GTE or green tea catechin consumption. Therefore, it is recommended to avoid, or at least use caution in, consuming large amounts of green tea daily or ingesting GTE supplements in patients receiving medications known to serve as OATP substrates, particularly those which may have a narrow therapeutic index.

\section{Conflict of Interest}

The authors declare no conflicts of interest.

\section{References}

[1] Graham HN. Green tea composition, consumption, and polyphenol chemistry. Prev Med 1992; 21: 334-350

[2] Lin LZ, Chen P, Harnly JM. New phenolic components and chromatographic profiles of green and fermented teas. J Agric Food Chem 2008; 56: $8130-8140$

[3] Xu JZ, Yeung SYV, Chang Q, Huang Y, Chen ZY. Comparison of antioxidant activity and bioavailability of tea epicatechins with their epimers. Br J Nutr 2004; 91: 873-881

[4] Lin JK, Lin CL, Liang YC, Lin-Shiau SY, Juan IM. Survey of catechins, gallic acid, and methylxanthines in green, oolong, pu-erh, and black teas. J Agric Food Chem 1998; 46: 3635-3642

[5] Gormaz JG, Valls N, Sotomayor C, Turner T, Rodrigo R. Potential role of polyphenols in the prevention of cardiovascular diseases: molecular bases. Curr Med Chem 2016; 23: 115-128

[6] McKenna DJ, Hughes K, Jones K. Green tea monograph. Altern Ther Health Med 2000; 6: 61-68, 70-72, 74 passim

[7] Nagle DG, Ferreira D, Zhou YD. Epigallocatechin-3-gallate (EGCG): chemical and biomedical perspectives. Phytochemistry 2006; 67: 1849-1855

[8] Wang H, Wen Y, Du Y, Yan X, Guo H, Rycroft JA, Boon N, Kovacs EMR, Mela DJ. Effects of catechin enriched green tea on body composition. Obesity (Silver Spring) 2010; 18: 773-779

[9] Liu K, Zhou R, Wang B, Chen K, Shi LY, Zhu JD, Mi MT. Effect of green tea on glucose control and insulin sensitivity: a meta-analysis of 17 randomized controlled trials. Am J Clin Nutr 2013; 98: 340-348

[10] Nagao T, Hase T, Tokimitsu I. A green tea extract high in catechins reduces body fat and cardiovascular risks in humans. Obesity (Silver Spring) 2007; 15: 1473-1483

[11] Gurley B], Fifer EK, Gardner Z. Pharmacokinetic herb-drug interactions (part 2): drug interactions involving popular botanical dietary supplements and their clinical relevance. Planta Med 2012; 78: 1490-1514

[12] Muto S, Fujita K, Yamazaki Y, Kamataki T. Inhibition by green tea catechins of metabolic activation of procarcinogens by human cytochrome P450. Mutat Res 2001; 479: 197-206

[13] Nishikawa M, Ariyoshi N, Kotani A, Ishii I, Nakamura H, Nakasa H, Ida M, Kimura N, Kimura M, Hasegawa A, Kusu F, Ohmori S, Nakazawa K, Kitada $M$. Effects of continuous ingestion of green tea or grape seed extracts on the pharmacokinetics of midazolam. Drug Metab Pharmacokinet 2004; 19: $280-289$

[14] Mirkov S, Komoroski B], Ramírez J, Graber AY, Ratain MJ, Strom SC, Innocenti F. Effects of green tea compounds on irinotecan metabolism. Drug Metab Dispos 2007; 35: 228-233

[15] Misaka S, Kawabe K, Onoue S, Werba JP, Giroli M, Tamaki S, Kan T, Kimura J, Watanabe $\mathrm{H}$, Yamada S. Effects of green tea catechins on cytochrome P450 2B6, 2C8, 2C19, 2D6 and 3A activities in human liver and intestinal microsomes. Drug Metab Pharmacokinet 2013; 28: 244-249 
[16] Netsch MI, Gutmann H, Schmidlin CB, Aydogan C, Drewe J. Induction of CYP1A by green tea extract in human intestinal cell lines. Planta Med 2006; 72: 514-520

[17] Satoh T, Fujisawa H, Nakamura A, Takahashi N, Watanabe K. Inhibitory effects of eight green tea catechins on cytochrome P450. J Pharm Pharm Sci 2016; 19: 188-197

[18] Mohamed ME, Frye RF. Inhibitory effects of commonly used herbal extracts on UDP-glucuronosyltransferase 1A4, 1A6, and $1 \mathrm{~A} 9$ enzyme activities. Drug Metab Dispos 2011; 39: 1522-1528

[19] Mohamed MF, Tseng T, Frye RF. Inhibitory effects of commonly used herbal extracts on UGT1A1 enzyme activity. Xenobiotica 2010; 40: 663-669

[20] Fuchikami H, Satoh H, Tsujimoto M, Ohdo S, Ohtani H, Sawada Y. Effects of herbal extracts on the function of human organic anion-transporting polypeptide OATP-B. Drug Metab Dispos 2006; 34: 577-582

[21] Roth M, Timmermann BN, Hagenbuch B. Interactions of green tea catechins with organic anion-transporting polypeptides. Drug Metab Dispos 2011; 39: 920-926

[22] Misaka S, Yatabe J, Müller F, Takano K, Kawabe K, Glaeser H, Yatabe MS, Onoue S, Werba JP, Watanabe $\mathrm{H}$. Green tea ingestion greatly reduces plasma concentrations of nadolol in healthy subjects. Clin Pharmacol Ther 2014; 95: 432-438

[23] Netsch MI, Gutmann H, Luescher S, Brill S, Schmidlin CB, Kreuter MH, Drewe J. Inhibitory activity of a green tea extract and some of its constituents on multidrug resistance-associated protein 2 functionality. Planta Med 2005; 71: 135-141

[24] Jodoin ], Demeule M, Béliveau R. Inhibition of the multidrug resistance Pglycoprotein activity by green tea polyphenols. Biochim Biophys Acta 2002; 1542: 149-159

[25] Knop ], Misaka S, Singer K, Hoier E, Muller F, Glaeser H, Konig J, Fromm MF. Inhibitory effects of green tea and (-)-epigallocatechin gallate on transport by OATP1B1, OATP1B3, OCT1, OCT2, MATE1, MATE2-K and Pglycoprotein. PLoS One 2015; 10: e0139370

[26] Jaiyen C, Jutabha P, Anzai N, Lungkaphin A, Soodvilai S, Srimaroeng C. Interaction of green tea catechins with renal organic cation transporter 2. Xenobiotica 2015; 46: 1-10

[27] Ge J, Tan BX, Chen Y, Yang L, Peng XC, Li HZ, Lin HJ, Zhao Y, Wei M, Cheng K, Li LH, Dong H, Gao F, He JP, Wu Y, Qiu M, Zhao YL, Su JM, Hou JM, Liu JY. Interaction of green tea polyphenol epigallocatechin-3-gallate with sunitinib: potential risk of diminished sunitinib bioavailability. J Mol Med (Berl) 2011; 89: 595-602

[28] Li C, Choi JS. Effects of epigallocatechin gallate on the bioavailability and pharmacokinetics of diltiazem in rats. Pharmazie 2008; 63: 815-818

[29] Chung JH, Choi DH, Choi JS. Effects of oral epigallocatechin gallate on the oral pharmacokinetics of verapamil in rats. Biopharm Drug Dispos 2009; 30: 90-93

[30] Choi JS, Burm JP. Effects of oral epigallocatechin gallate on the pharmacokinetics of nicardipine in rats. Arch Pharm Res 2009; 32: 1721-1725

[31] Qiao ], Gu C, Shang W, Du J, Yin W, Zhu M, Wang W, Han M, Lu W. Effect of green tea on pharmacokinetics of 5-fluorouracil in rats and pharmacodynamics in human cell lines in vitro. Food Chem Toxicol 2011; 49: $1410-1415$

[32] Jang EH, Choi JY, Park CS, Lee SK, Kim CE, Park HJ, Kang JS, Lee JW, Kang $\mathrm{JH}$. Effects of green tea extract administration on the pharmacokinetics of clozapine in rats. J Pharm Pharmacol 2005; 57: 311-316

[33] Li C, Lim SC, Kim J, Choi JS. Effects of myricetin, an anticancer compound, on the bioavailability and pharmacokinetics of tamoxifen and its main metabolite, 4-hydroxytamoxifen, in rats. Eur J Drug Metab Pharmacokinet 2011; 36: 175-182

[34] Misaka S, Miyazaki N, Fukushima T, Yamada S, Kimura ]. Effects of green tea extract and (-)-epigallocatechin-3-gallate on pharmacokinetics of nadolol in rats. Phytomedicine 2013; 20: 1247-1250

[35] Misaka S, Kawabe K, Onoue S, Werba JP, Giroli M, Watanabe H, Yamada S. Green tea extract affects the cytochrome P450 3A activity and phar- macokinetics of simvastatin in rats. Drug Metab Pharmacokinet 2013; 28: 514-518

[36] Ezzeldin E, Asiri YA, Iqbal M. Effects of green tea extracts on the pharmacokinetics of quetiapine in rats. Evid Based Complement Alternat Med 2015; 2015: 615285

[37] Chow HH, Hakim IA, Vining DR, Crowell JA, Cordova CA, Chew WM, Xu MJ, Hsu CH, Ranger-Moore J, Alberts DS. Effects of repeated green tea catechin administration on human cytochrome P450 activity. Cancer Epidemiol Biomarkers Prev 2006; 15: 2473-2476

[38] Donovan JL, Chavin KD, Devane CL, Taylor RM, Wang JS, Ruan Y, Markowitz JS. Green tea (Camellia sinensis) extract does not alter cytochrome p450 3A4 or 2D6 activity in healthy volunteers. Drug Metab Dispos 2004; 32: 906-908

[39] Ullmann U, Haller ], Bakker GCM, Brink EJ, Weber P. Epigallocatechin gallate (EGCG) (TEAVIGOTM) does not impair nonhaem-iron absorption in man. Phytomedicine 2005; 12: 410-415

[40] Alemdaroglu NC, Dietz U, Wolffram S, Spahn-Langguth H, Langguth P. Influence of green and black tea on folic acid pharmacokinetics in healthy volunteers: potential risk of diminished folic acid bioavailability. Biopharm Drug Dispos 2008; 29: 335-348

[41] Markowitz JS, Zhu HJ. Limitations of in vitro assessments of the drug interaction potential of botanical supplements. Planta Med 2012; 78: 1421-1427

[42] Van Amelsvoort JM, Van Hof KH, Mathot JN, Mulder TP, Wiersma A, Tijburg LB. Plasma concentrations of individual tea catechins after a single oral dose in humans. Xenobiotica 2001; 31: 891-901

[43] Yang CS, Chen L, Lee MJ, Balentine D, Kuo MC, Schantz SP. Blood and urine levels of tea catechins after ingestion of different amounts of green tea by human volunteers. Cancer Epidemiol Biomarkers Prev 1998: $7: 351-354$

[44] Rowland A, Miners JO, Mackenzie PI. The UDP-glucuronosyltransferases: their role in drug metabolism and detoxification. Int J Biochem Cell Biol 2013; 45: 1121-1132

[45] Williams JA, Hyland R, Jones BC, Smith DA, Hurst S, Goosen TC, Peterkin $V$, Koup JR, Ball SE. Drug-drug interactions for UDP-glucuronosyltransferase substrates: a pharmacokinetic explanation for typically observed low exposure (AUCi/AUC) ratios. Drug Metab Dispos 2004; 32: 1201 1208

[46] Lu H, Meng X, Li C, Sang S, Patten C, Sheng S, Hong J, Bai N, Winnik B, Ho $\mathrm{CT}$, Yang CS. Glucuronides of tea catechins: enzymology of biosynthesis and biological activities. Drug Metab Dispos 2003; 31: 452-461

[47] Jinno H, Tanaka-Kagawa T, Hanioka N, Saeki M, Ishida S, Nishimura T, Ando M, Saito Y, Ozawa S, Sawada JI. Glucuronidation of 7-ethyl-10hydroxycamptothecin (SN-38), an active metabolite of irinotecan (CPT-11), by human UGT1A1 variants, G71R, P229Q, and Y486D. Drug Metab Dispos 2003; 31: 108-113

[48] Molassiotis A, Fernadez-Ortega P, Pud D, Ozden G, Scott JA, Panteli V, Margulies A, Browall M, Magri M, Selvekerova S, Madsen E, Milovics L, Bruyns I, Gudmundsdottir G, Hummerston S, Ahmad AM, Platin N, Kearney N, Patiraki E. Use of complementary and alternative medicine in cancer patients: a European survey. Ann Oncol 2005; 16: 655-663

[49] Edge SC, Markowitz JS, Devane CL. Clozapine drug-drug interactions: a review of the literature. Hum Psychopharmacol 1997; 12: 5-20

[50] Gurley B], Markowitz JS, Williams DK, Barone GW. Practical considerations when designing and conducting clinical pharmacokinetic herbdrug interaction studies. Int J Pharmacokinet 2016; DOI: 10.4155/ipk2016-0009

[51] Ide K, Park M, Yamada H. The effect of green tea with exceptionally high catechin content on nadolol plasma concentration. Clin Pharmacol Ther 2014; 95: 588

[52] Nakagawa S, Hoshi T, Kubo A, Yamato S. Determination of tea polyphenols in bottled Japanese tea drinks and differences in polyphenol content in tea leaves from different variety. Bunseki Kagaku 2013; 62: 51-55 